\title{
Legge, Lois. (2019). Wounded Hearts: Memories of the Halifax Protestant Orphans' Home. Halifax: Nimbus Publishing Limited.
}

\author{
Reviewed by: Ryan Duchnowski, MacEwan University
}

Lois Legge's book, "Wounded Hearts", is a book written to retell accounts from people who were put into an orphanage known as the "Halifax Protestant Orphans Home". The orphanage was open in the year 1857 and was eventually closed in 1970. Between those 113 years of operation, many children went through the home, and most speak of abuse and neglect that happened within the four walls of that building. This book shared the experiences of eight individuals who spent time inside the orphanage in the 1900's. This book also talks about the greater system that was put in place in Halifax at the time when it came to childcare and highlights

some of the flaws that were inside the system which led to such neglect and abuse at this orphanage. Each of the first eight chapters are dedicated to a specific individual who is telling their story about the orphanage, while the last few chapters talk about the building that used to be the orphanage and what it has turned into now after closing in 1970.

All eight people who were contacted for this book to tell their story, share some similarities. First off, they all came from mostly broken families who had a mother and/or father who dealt with addiction or were too poor to care for their kids, or simply they passed away. In most instances 
that addiction was alcohol, which led in some cases to severe forms of alcoholism. They would be unable to provide for their children, so the Halifax child protection services would take them away and put them into different homes, one of them being this orphanage. The orphanage was run by women who were known as "matrons", with one head matron at the top to oversee everything. The orphanage was privately owned and sustained throughout the years from generous donations from wealthy individuals and eventually with help from the province itself for funding. These institutions were getting paid roughly $\$ 5$ a week, per child, that was inside the orphanage (p. 213). Conclusions could be drawn that the orphanage was run more of like a business, rather than a place to actual care for children. So, if there were children coming into this orphanage, it was making money for the private owners. In those times, orphans were seen as below regular children, often as a paycheque to the orphanage, and were often ridiculed by the outside society. As said by one of the people recounting their time "They'd pick up sticks... and they'd run back and forth with this stick on the wrought-iron fence; it would be clacking back and forth and they'd be yelling at us: 'Orphans orphans, orphans!' And sometimes they'd throw rocks at us, and sticks. It was pretty traumatic (p. 75)". The children would get beaten with paddles and sticks for misbehaving or told to go into a dark closet for a period of time. "James often watched the discipline, as did others, when the matrons hit the boys and girls with the wooden paddles other former residents have described... It was always like a public spectacle" (p. 145). Sometimes these children would move to foster care, but the vetting process back then for potential foster families is not what it is today. Children would get beaten and smacked and mistreated by their foster families, because the province paid a weekly wage to these families to take care of the children, so they were also just 
another source of income for the family. Sometimes the children would be abused by their foster family and sent back to the orphanage. "There were no case reviews. Not one time did social services ever come and do a case review with us, saying, 'How are you getting along? Are you getting enough to eat?' None of that. 'How are you treated?' No. So really we fended for ourselves” (p. 159).

The accountability of these institutions was almost nonexistent. Each year they would be sent a simple questionnaire to fill out regarding how things were going. Questions included "Are records of punishment kept? Is corporal punishment administered? Is solitary confinement used as punishment? (p. 211). Most of the times these institutions would simply answer "no" to all these questions and would move on to the next year. There were inspections that would happen somewhat occasionally at these orphanages, but the matrons were told well in advance when these days would be. For those days, they would dress up the children, give them toys and other props to play with, and put on this façade that everything was going well and that the children were happy. As soon as the people left the orphanage, they would be stripped of their clothes, their toys would be taken away, and go back to being miserable in ragged clothes. There are pictures that Legge includes throughout the book, given to her by the very people who spent time in this orphanage. They are all happy in the pictures, but absolutely torn and wrecked on the inside. Children suffered both physical and metal abuse at the hands of these matrons, and the effects of this abuse was life-lasting.

The building now is home to what is called the "Veith House". It is a social space for those less fortunate and privileged to come and spend time with one another and access services. There 
are memorial plaques inside and outside the house now to pay homage to all of the children who suffered while going through this orphanage in the 1900's. It is a place where people can gather and find a sense of community and belonging, in a world where belonging is not always so easy to find. They also have a memorial room that previous people who suffered abuse at the orphanage can come and "try to heal" in any way they can. They acknowledge the abuse and neglect in the past that occurred but want to try and turn it into a "happy place" (p.190).

Legge states near the beginning of the book that the purpose of it was "... in some small way, to help heal these wounded hearts of long ago" (p. 5). The intended academic audience of this book is mostly historians, but also people involved in child welfare, both administratively and more hands-on. The book also would appeal to sociologists when studying things like the human condition and childhood trauma, and the long-term effects it has on people as they grow older. This book can be difficult to read at times, with some of the accounts given by the people, but it is important to understand the historical significance of this book, and to learn from our past mistakes, to not repeat them again.

I personally found this book quite interesting to read. Coming from a very privileged background, I can sympathize with the experiences those children had to go through all those years ago. They were dealt a very poor hand in life and ended up suffering at the hands of these adults who were supposed to be taking care of them and helping nurture them into productive members of society. Instead, they were almost thrown to the wayside and treated as walking paycheques for the orphanages and foster families who took them in. The idea that these kids, who were in their adolescents, be beaten and punished in cruel ways to help discipline them, is heart shattering. This 


\section{Duchnowski}

book is structured very well and pulls the reader in with these recounts of people of all those years ago. It pulls at the heartstrings of readers and offers some solace to those who might have gone through something similar in the past. "Many of the former residents have shown tremendous resilience, going on to successful careers. But it's often a struggle in the aftermath" (p. 48). 